[Article]

\title{
Fe-P体系热力学再优化
}

\author{
曹战民* 王昆鹏 乔芝郁 杜广巍 \\ (北京科技大学, 钢铁冶金新技术国家重点实验室, 冶金与生态工程学院, 北京 100083)
}

\begin{abstract}
摘要: 基于最新的实验热力学数据和相图数据, 采用 CALPHAD 技术对 Fe-P 体系进行热力学再优化. 其中, 溶液相(液相、 $\alpha-\mathrm{Fe}$ 和 $\gamma-\mathrm{Fe}$ )的 Gibbs 自由能用替换溶液模型描述, 其余化合物 $\left(\mathrm{Fe}_{3} P 、 \mathrm{Fe}_{2} \mathrm{P} 、 \mathrm{FeP} 、 \mathrm{FeP}_{2}\right.$ 和 $\mathrm{FeP}_{4}$ ) 看作严格计量比化合物. 整个优化过程在 Thermo-Calc ${ }^{\circledR}$ 软件包中完成, 优化所得热力学数据和相图信息与实 验信息吻合较好, 为 $\mathrm{Fe}$ 基合金和含 $\mathrm{P}$ 多元合金体系的进一步优化提供了一组自洽可靠的热力学参数.
\end{abstract}

关键词：Fe-P体系；CALPHAD技术；相图；热力学优化

中图分类号: 0642

\section{Thermodynamic Reoptimization of the Fe-P System}

\author{
CAO Zhan-Min* WANG Kun-Peng QIAO Zhi-Yu DU Guang-Wei \\ (State Key Laboratory of Advanced Metallurgy, School of Metallurgical and Ecological Engineering, \\ University of Science \& Technology Beijing, Beijing 100083, P. R. China)
}

\begin{abstract}
The Fe-P binary system was reoptimized by means of the CALPHAD approach. The Gibbs energy descriptions of every phase in the Fe-P binary system were optimized based on the latest experimental thermodynamic and phase diagram data. The solution phase (liquid, $\alpha$ - $\mathrm{Fe}$, and $y$ - $\mathrm{Fe}$ ) was described by the substitutional solution approximation and the other phases $\left(\mathrm{Fe}_{3} \mathrm{P}, \mathrm{Fe}_{2} \mathrm{P}, \mathrm{FeP}, \mathrm{FeP}_{2}\right.$, and $\mathrm{FeP}_{4}$ ) were treated as the stoichiometric compounds. The optimization was carried out using the Thermo-Calc ${ }^{\circledR}$ software package. The agreement of the optimized phase diagram and thermodynamic data with experimental results is good, and a self-consistent and reliable thermodynamic dataset is obtained to allow further optimization of Fe-based, P-containing multicomponent alloy systems.
\end{abstract}

Key Words: Fe-P system; CALPHAD approach; Phase diagram; Thermodynamic optimization

\section{Introduction}

Fe-P is a fundamental binary system of the Fe-based and P-containing multicomponent alloys, which are of great importance for the advanced metallurgy and materials, such as stainless steel, ultra-pure steel refining, and materials design and processing. From thermodynamic point of view, the best optimized parameters of the Fe-P binary system are a quite important basis for thermodynamic optimization of the Fe-based and P-containing multicomponent systems. Also, thermodynamic data of the Fe-P system with strong interactions advance a better understanding of the nature of chemical bonding and inter- action mechanism. As pointed out by Okamoto ${ }^{1}$ in a critical assessment of the Fe-P system, the assessed Fe-P phase diagram was accepted primarily from Kubaschewski ${ }^{2}$ in 1982. Recently, Ohtani et al..$^{3}$ in 2006 and Tokunaga et al. ${ }^{4}$ in 2009 evaluated thermodynamic parameters and calculated phase diagram of the Fe-P system in the thermodynamic analysis of the Fe-Ti-P and $\mathrm{Fe}-\mathrm{Nb}-\mathrm{P}$ systems, respectively. But, in both evaluations the valuable thermodynamic properties in the Fe-P system measured by Zaitsev et al. ${ }^{5}$ using differential scanning calorimetry and Knudsen effusion method with mass-spectrometric analysis of the gaseous phase were omitted. In order to obtain a set

Received: October 8, 2011; Revised: November 14, 2011; Published on Web: November 17, 2011.

"Corresponding author. Email: zmcao@ustb.edu.cn; Tel: +86-13671040866.

The project was supported by the National Natural Science Foundation of China (50934011).

国家自然科学基金(50934011)资助项目

(C) Editorial office of Acta Physico-Chimica Sinica 
of self-consistent and reliable thermodynamic description for this binary system, it is necessary to reoptimize the Fe-P system with all available thermodynamic and phase equilibria data using CALPHAD approach ${ }^{6,7}$ and Thermo-Calc ${ }^{\circledR}$ software package. ${ }^{8}$

\section{Experimental phase diagram data}

Due to the practical and theoretical importance many authors investigated the phase equilibria of the Fe-P system. Saklatwalla ${ }^{9}$ firstly published the phase relationship of the Fe-P (0\%-24\% P, mass fraction) system. Then, Konstantinow ${ }^{10}$ and Haughton ${ }^{11}$ measured the phase diagram of the Fe-P system up to $24 \% \mathrm{P}$ and $32 \% \mathrm{P}$, respectively, and showed the existence of liquid (L) phase and $\alpha$-Fe, $\gamma$-Fe, $\mathrm{Fe}_{3} \mathrm{P}, \mathrm{Fe}_{2} \mathrm{P}, \mathrm{FeP}$ phases. The solubility of $\mathrm{P}$ in $\gamma$-Fe was measured by several investigators, including Vogel $^{12}$ and Roquet et al. ${ }^{13}$ using metallography as well as Lorenz ${ }^{14}$ and Fisher ${ }^{15}$ et al. using magnetic measurements, respectively. The assessed maximum solubility of $\mathrm{P}$ in $\gamma$-Fe is ca $0.56 \%$ at $1423 \mathrm{~K}^{2,12}$ The liquidus and solidus of $\alpha$-Fe were measured by many researchers. ${ }^{9,11,16-19}$ The quantitative values of solid solubility of $\mathrm{P}$ in $\alpha$-Fe were obtained by using metallography, ${ }^{11,12,17,20} \mathrm{X}$-ray analysis, ${ }^{21,22}$ precipitation hardening, ${ }^{23}$ lattice parameter measurements, ${ }^{24}$ electron probe analysis, ${ }^{25}$ microprobe and micro-hardness tests, ${ }^{26}$ and X-ray microanalyzer. ${ }^{27}$ The experimental results obtained from different investigators established that three invariant reactions exist in the Fe-P system, i.e., $\mathrm{L} \rightleftharpoons \alpha$-Fe+Fe $\mathrm{Fe}_{3} \mathrm{P}, \mathrm{L}+\mathrm{Fe}_{2} \mathrm{P} \rightleftharpoons \mathrm{Fe}_{3} \mathrm{P}$, and $\mathrm{L} \rightleftharpoons \mathrm{Fe}_{2} \mathrm{P}+$ FeP. But, as shown in Table 1 there are small differences for the temperature and composition of the invariant points. Franke et al. ${ }^{28}$ Meisel, ${ }^{29}$ and Heimbrecht et al.$^{30}$ revealed the existence of $\mathrm{FeP}_{2}$ by use of density and X-ray diffraction measurements. Holseth et al. ${ }^{31}$ measured the maximum homogeneity range of $\mathrm{FeP}_{2}$ from $65.6 \% \mathrm{P}$ to $66.9 \% \mathrm{P}$ and from $66.2 \% \mathrm{P}$ to $67.1 \% \mathrm{P}$, respectively. Jeitschko et al. ${ }^{32}$ synthesized monoclinic $\mathrm{FeP}_{4}$ from the elements at 927 to $627^{\circ} \mathrm{C}$ using iodine as a catalyst and tin as a flux. Up to now, no experimental information about the phase relationship of the Fe-P ( $0 \%$ to $100 \%$ P) system was reported.

\section{Experimental thermodynamic property data}

Weibke et al. ${ }^{33}$ experimentally measured the formation enthalpies $\left(\Delta_{\mathrm{f}} H\right)$ of $\mathrm{Fe}_{3} \mathrm{P}$ and $\mathrm{Fe}_{2} \mathrm{P}$ at $908 \mathrm{~K}$ by using an adiabatic calorimeter as well as Lewis et al. ${ }^{34}$ calculated formation enthalpies of $\mathrm{Fe}_{2} \mathrm{P}, \mathrm{FeP}, \mathrm{FeP}_{2}$ at $900 \mathrm{~K}$ from their temperature dependences of the dissociation pressures measured by Knudsen effusion method. Based on the available thermodynamic and phase equilibria data, Spencer et al. ${ }^{35}$ evaluated the thermodynamic properties of $\mathrm{Fe}_{3} \mathrm{P}, \mathrm{Fe}_{2} \mathrm{P}, \mathrm{FeP}$, and $\mathrm{FeP}_{2}$, including heat capacity $\left(C_{p}\right)$, mixing enthalpy $\left(\Delta_{\text {mix }} H\right)$, formation entropy $\left(\Delta_{\uparrow} S\right)$, formation enthalpy $\left(\Delta_{\mathrm{f}} H\right)$, and Gibbs energy of formation $\left(\Delta_{\mathrm{f}} G\right)$. As mentioned, Zaitsev et al. ${ }^{5}$ measured the heat capacities of iron phosphides $\mathrm{Fe}_{3} \mathrm{P}, \mathrm{Fe}_{2} \mathrm{P}$, and $\mathrm{FeP}$ in the temperature range of $113-873 \mathrm{~K}$ and investigated the thermodynamic properties of iron phosphides (1041-1549 K), bec solid solution Fe-P (1384-1619 K), and Fe-P liquid alloys (1349-1811 K) by means of Knudsen effusion method with mass-spectrometric analysis of the gaseous phase. Then, based on the experimentally measured results and the second and third thermodynamic laws, $\Delta_{\mathrm{f}} G-T$ relationships of the $\mathrm{Fe}_{3} \mathrm{P}, \mathrm{Fe}_{2} \mathrm{P}$, and $\mathrm{FeP}$ at $1230-1530 \mathrm{~K}, \Delta_{\mathrm{f}} H, \Delta_{\mathrm{f}} S$, and $S^{\ominus}$ (absolute entropy) at $298 \mathrm{~K}$, as well as activities of $\mathrm{P}$ in liquid phase and in $\alpha$-Fe were determined. Little experimental thermodynamic data of $\mathrm{FeP}_{2}$ and $\mathrm{FeP}_{4}$ and phase relation information concerning the Fe-P $(50 \%-100 \%)$ system existed in literature due to high volatility of phosphorus at elevated temperature. Therefore, the calculated formation enthalpies of $\mathrm{FeP}_{2}$ and $\mathrm{FeP}_{4}$ in the Fe-P system at $298 \mathrm{~K}$ by first-principles method ${ }^{3}$ were used as initial values in the present optimization. All thermodynamic data used in the present optimization are summarized in Table 2.

\section{Thermodynamic models and optimization 4.1 Reference states}

As reference states for the investigated system, the pure solid elements in their stable states at $298.15 \mathrm{~K}$ and $10^{5} \mathrm{~Pa}$ (stable element reference, SER) were chosen. The Gibbs energy of the element $i$ with $\Phi$ phase appears in the following form:

$$
\begin{aligned}
{ }^{0} G_{i}^{\Phi}(T) & =G_{i}^{\Phi}(T)-H_{i}^{\mathrm{SER}}(298.15 \mathrm{~K}) \\
& =a+b T+c T^{2}+d T^{3}+e T^{-1}+f T \ln T+g T^{-9}
\end{aligned}
$$

where $H_{i}^{\text {SER }}$ is the enthalpy of the element $i$ in its SER state at $298.15 \mathrm{~K}$ and $10^{5} \mathrm{~Pa} ; T$ is the absolute temperature in $\mathrm{K} ; G_{i}^{\Phi}(T)$ is the Gibbs energy of the element $i ;{ }^{0} G_{i}^{\Phi}(T)$ is the molar Gibbs energy of the element $i$ with the structure of $\Phi$ referred to the enthalpy of its stable state at $298.15 \mathrm{~K}$ and $10^{5} \mathrm{~Pa}$, which is denoted by GHSER $i$ when the element $i$ is in its stable state. Different sets of coefficients $a$ to $g$ used in different temperature ranges in Eq.(1) and compiled by the SGTE (Scientific Group Thermodata Europe) database ${ }^{36}$ were chosen. The used lattice stability parameters for $\mathrm{Fe}$ and $\mathrm{P}$ are summarized in Table 3.

\subsection{Stoichiometric intermetallic compounds}

In the Fe-P system intermetallic compounds $\mathrm{Fe}_{3} \mathrm{P}, \mathrm{FeP}$, and $\mathrm{FeP}_{4}$ belong to the stoichiometric phases. Even small solubility of $\mathrm{P}$ in $\mathrm{Fe}_{2} \mathrm{P}$ and $\mathrm{FeP}_{2}$ was reported, ${ }^{31,37} \mathrm{Fe}_{2} \mathrm{P}$ and $\mathrm{FeP}_{2}$ were also approximately treated as intermetallic compounds. The Gibbs energy per mole $\mathrm{Fe}_{3} \mathrm{P}, \mathrm{Fe}_{2} \mathrm{P}$, and $\mathrm{FeP}$ is given as:

$$
{ }^{0} G_{\mathrm{m}}^{\Phi}(T)=a+b T+\int_{298.15 \mathrm{~K}}^{T} C_{p} \mathrm{~d} T-T \int_{298.15 \mathrm{~K}}^{T} \frac{C_{p}}{T} \mathrm{~d} T
$$

where $C_{p}$ is isobaric molar heat capacity, the coefficients of $a$ and $b$ will be optimized using $\Delta_{\mathrm{f}} H_{298.15 \mathrm{~K}}^{\ominus}, S_{298.15 \mathrm{~K}}^{\ominus}$ as initial values. The measured values of $C_{p}$ reported by Zaitsev et al. ${ }^{5}$ were also used in the present optimization.

The Gibbs energy per mole $\mathrm{FeP}_{2}$ and $\mathrm{FeP}_{4}$ can be expressed as follows:

$$
{ }^{0} G_{\mathrm{m}}^{\mathrm{Fe}_{m} \mathrm{P}_{n}}(T)=m \text { GHSERFe }+n \text { GHSERP }+\Delta_{\mathrm{f}} G^{\mathrm{Fe}_{m} \mathrm{P}_{n}}
$$
where ${ }^{0} G_{\mathrm{m}} \mathrm{Fe}_{m} \mathrm{P}_{n}(T)$ denotes the standard Gibbs energy of forma- 
Table 1 Invariant reactions of the Fe-P system

\begin{tabular}{|c|c|c|c|c|}
\hline Reaction & Reaction type & $\mathrm{P}$ composition in the liquid/\% & $T / \mathrm{K}$ & Reference \\
\hline \multirow[t]{13}{*}{$\mathrm{L} \rightleftharpoons \alpha-\mathrm{Fe}+\mathrm{Fe}_{3} \mathrm{P}$} & eutectic & $\sim 17$ & $\sim 1253$ & $16^{\mathrm{a}}$ \\
\hline & & 16.7 & 1278 & $9^{a}$ \\
\hline & & 16.6 & 1293 & $10^{\mathrm{a}}$ \\
\hline & & $\sim 17$ & 1323 & $11^{\mathrm{a}}$ \\
\hline & & 22.5 & $1313 \pm 10$ & $25^{\mathrm{a}}$ \\
\hline & & $\sim 17$ & 1321 & $18^{\mathrm{a}}$ \\
\hline & & $\sim 17$ & 1312 & $19^{\mathrm{a}}$ \\
\hline & & 17 & 1321 & $2^{\mathrm{b}}$ \\
\hline & & 17.4 & 1321 & $1^{b}$ \\
\hline & & 16.7 & 1320 & $5^{\mathrm{b}}$ \\
\hline & & 16.3 & 1323 & $3^{\mathrm{b}}$ \\
\hline & & 16.9 & 1321 & $35^{\mathrm{b}}$ \\
\hline & & 16.5 & 1324 & this work \\
\hline \multirow[t]{9}{*}{$\mathrm{L}+\mathrm{Fe}_{2} \mathrm{P} \rightleftharpoons \mathrm{Fe}_{3} \mathrm{P}$} & peritectic & 24.4 & $\sim 1428$ & $10^{\mathrm{a}}$ \\
\hline & & 24.2 & 1439 & $11^{a}$ \\
\hline & & 24.3 & 1446 & $19^{\mathrm{a}}$ \\
\hline & & 24.0 & 1439 & $2^{\mathrm{b}}$ \\
\hline & & 24.0 & 1439 & $1^{b}$ \\
\hline & & 24.3 & 1439 & $5^{\mathrm{b}}$ \\
\hline & & 23.1 & 1438 & $3^{\mathrm{b}}$ \\
\hline & & 24.5 & 1439 & $35^{\mathrm{b}}$ \\
\hline & & 23.8 & 1437 & this work \\
\hline \multirow[t]{7}{*}{$\mathrm{L} \rightleftharpoons \mathrm{Fe}_{2} \mathrm{P}+\mathrm{FeP}$} & eutectic & 40 & 1535 & $10^{\mathrm{a}}$ \\
\hline & & 40 & 1538 & $19^{\mathrm{a}}$ \\
\hline & & 40 & 1535 & $2^{\mathrm{b}}$ \\
\hline & & 40 & 1535 & $1^{b}$ \\
\hline & & 39.9 & 1534 & $5^{\mathrm{b}}$ \\
\hline & & 40.4 & 1533 & $3^{\mathrm{b}}$ \\
\hline & & 40.1 & 1534 & this work \\
\hline \multirow[t]{4}{*}{$\mathrm{L} \rightleftharpoons \mathrm{Fe}_{2} \mathrm{P}$} & melting point & 33.3 & 1543 & $9^{\mathrm{a}}$ \\
\hline & & 33.3 & 1623 & $10^{\mathrm{a}}$ \\
\hline & & 33.3 & 1643 & $11^{a}$ \\
\hline & & 33.3 & 1642 & this work \\
\hline \multirow[t]{2}{*}{$\mathrm{L} \rightleftharpoons \mathrm{Fe}_{2} \mathrm{P}+\mathrm{FeP}$} & eutectic & 40 & 1535 & $11^{\mathrm{a}}$ \\
\hline & & 40 & 1534 & this work \\
\hline $\mathrm{L} \rightleftharpoons \mathrm{FeP}$ & melting point & 50 & 1724 & this work \\
\hline $\mathrm{L} \rightleftharpoons \mathrm{FeP}+\mathrm{FeP}_{2}$ & eutectic & 55.9 & 1660 & this work \\
\hline $\mathrm{L} \rightleftharpoons \mathrm{FeP}_{2}$ & melting point & 75.0 & 1799 & this work \\
\hline $\mathrm{L} \rightleftharpoons \mathrm{Fe}_{2} \mathrm{P}+\mathrm{FeP}_{4}$ & eutectic & 73.2 & 1750 & this work \\
\hline $\mathrm{L} \rightleftharpoons \mathrm{FeP}_{4}$ & melting point & 80 & 1799 & this work \\
\hline $\mathrm{L} \rightleftharpoons$ red_P+FeP ${ }_{4}$ & eutectic & $\sim 100$ & 852 & this work \\
\hline
\end{tabular}

${ }^{\mathrm{a} m e a s u r e d ;}{ }^{\mathrm{b} a s s e s s e d}$

tion per mole formula of $\mathrm{Fe}_{m} \mathrm{P}_{n}$. Due to the lack of experimental data of heat capacities, by applying to the Neumann-Kopp rule, $\Delta_{\mathrm{f}} G^{\mathrm{Fe}_{m} \mathrm{P}_{n}}$ can be given as follows:

$$
\Delta \mathrm{f} G^{\mathrm{Fe}_{m} \mathrm{P}_{n}}=a+b T
$$

where the parameters $a$ and $b$ were to be evaluated in the present work.

\subsection{Solution phases}

There are three solution phases in the Fe-P system, i.e., liquid phase, bcc $(\alpha-\mathrm{Fe})$, and fcc $(\gamma-\mathrm{Fe})$. The Gibbs energy of the solution phase in the Fe-P system is described as follows:

${ }^{0} G_{\mathrm{m}}^{\Phi}=x_{\mathrm{Fe}}{ }^{0} G_{\mathrm{Fe}}^{\Phi}(T)+x_{\mathrm{P}}^{0} G_{\mathrm{P}}^{\Phi}(T)+R T\left(x_{\mathrm{Fe}} \ln x_{\mathrm{Fe}}+x_{\mathrm{P}} \ln x_{\mathrm{P}}\right)+{ }^{\mathrm{E}} G_{\mathrm{m}}^{\Phi}$ (5) where ${ }^{\mathrm{E}} G_{\mathrm{m}}^{\Phi}$ is excess molar Gibbs energy, which can be expressed by Redlich-Kister polynomial ${ }^{38}$ as,

$$
{ }^{\mathrm{E}} G_{\mathrm{m}}=x_{\mathrm{Fe}} x_{\mathrm{P}}\left[L_{0}+\left(x_{\mathrm{Fe}}-x_{\mathrm{P}}\right) L_{1}+\left(x_{\mathrm{Fe}}-x_{\mathrm{P}}\right)^{2} L_{\mathrm{P}}\right]
$$

where $L_{i}(i=0,1,2, \cdots)$ are the $i$-order interaction parameters of liquid phase in the Fe-P system and are expressed as temperature dependent terms as follows: 
Table 2 Thermodynamic data in the Fe-P system (reference states: $\alpha$-Fe and red_P)

\begin{tabular}{|c|c|c|c|c|}
\hline Thermodynamic function & Phase & Method & Value & Reference \\
\hline \multirow[t]{2}{*}{$C_{p} /\left(\mathrm{J} \cdot \mathrm{mol}^{-1} \cdot \mathrm{K}^{-1}\right)$} & $\mathrm{Fe}_{3} \mathrm{P}$ & DSC & $27.725+2.925 \times 10^{-3} T-2.6975 \times 10^{5} T^{-2}(298-633 \mathrm{~K})$ & 5 \\
\hline & & & $(21.40 \pm 0.29)+(1.125 \pm 0.173) \times 10^{-2} T(713-873 \mathrm{~K})$ & 5 \\
\hline$C_{p} /\left(\mathrm{J} \cdot \mathrm{mol}^{-1} \cdot \mathrm{K}^{-1}\right)$ & $\mathrm{Fe}_{2} \mathrm{P}$ & DSC & $(22.22 \pm 0.24)+(9.6 \pm 0.4) \times 10^{-3} T(298-873 \mathrm{~K})$ & 5 \\
\hline$C_{p} /\left(\mathrm{J} \cdot \mathrm{mol}^{-1} \cdot \mathrm{K}^{-1}\right)$ & $\mathrm{FeP}$ & DSC & $(21.13 \pm 0.175)+(1.05 \pm 0.03) \times 10^{-2} T(298-873 \mathrm{~K})$ & 5 \\
\hline \multirow[t]{3}{*}{$S_{298 \mathrm{~K}}^{\ominus} /\left(\mathrm{J} \cdot \mathrm{mol}^{-1} \cdot \mathrm{K}^{-1}\right)$} & $\mathrm{Fe}_{3} \mathrm{P}$ & the third law calculation & $29.3 \pm 2.7$ & 5 \\
\hline & & $\mathrm{C}_{p}$ measurements & $27.4 \pm 2.0$ & 5 \\
\hline & & the third law calculation & $25.4 \pm 3.1$ & 35 \\
\hline \multirow[t]{3}{*}{$S_{298 \mathrm{~K}}^{\ominus} /\left(\mathrm{J} \cdot \mathrm{mol}^{-1} \cdot \mathrm{K}^{\mathrm{vl}}\right)$} & $\mathrm{Fe}_{2} \mathrm{P}$ & the third law calculation & $28.8 \pm 2.2$ & 5 \\
\hline & & $\mathrm{C}_{p}$ measurements & $30.2 \pm 1.7$ & 5 \\
\hline & & the third law calculation & $24.1 \pm 2.8$ & 35 \\
\hline \multirow[t]{2}{*}{$S_{298 \mathrm{~K}}^{\ominus} /\left(\mathrm{J} \cdot \mathrm{mol}^{-1} \cdot \mathrm{K}^{-1}\right)$} & $\mathrm{FeP}$ & the third law calculation & $25.4 \pm 3.3$ & 5 \\
\hline & & $\mathrm{C}_{p}$ measurements & $28.5 \pm 2.5$ & 5 \\
\hline \multirow[t]{3}{*}{$\Delta_{\mathrm{f}} H_{298 \mathrm{~K}} /\left(\mathrm{kJ} \cdot \mathrm{mol}^{-1}\right)$} & $\mathrm{Fe}_{3} \mathrm{P}$ & the second law analysis & $-35.1 \pm 2.4$ & 5 \\
\hline & & the second law analysis & $-36.7 \pm 2.1$ & 35 \\
\hline & & first-principles calculations & -48.4 & 3 \\
\hline$\Delta_{\mathrm{f}} H_{1200 \mathrm{~K}} /\left(\mathrm{kJ} \cdot \mathrm{mol}^{-1}\right)$ & $\mathrm{Fe}_{3} \mathrm{P}$ & the second law analysis & -39.0 & 5 \\
\hline$\Delta_{\mathrm{f}} H_{908 \mathrm{~K}} /\left(\mathrm{kJ} \cdot \mathrm{mol}^{-1}\right)$ & $\mathrm{Fe}_{3} \mathrm{P}$ & calorimetric measurement & -36.8 & 33 \\
\hline \multirow[t]{3}{*}{$\Delta_{\mathrm{f}} H_{298 \mathrm{~K}} /\left(\mathrm{kJ} \cdot \mathrm{mol}^{-1}\right)$} & $\mathrm{Fe}_{2} \mathrm{P}$ & the second law analysis & $-46.2 \pm 2.2$ & 5 \\
\hline & & the second law analysis & $-47.6 \pm 2.8$ & 35 \\
\hline & & first-principles calculations & -54.6 & 3 \\
\hline$\Delta_{\mathrm{f}} H_{900 \mathrm{~K}} /\left(\mathrm{kJ} \cdot \mathrm{mol}^{-1}\right)$ & $\mathrm{Fe}_{2} \mathrm{P}$ & Knudsen effusion & -49.1 & 34 \\
\hline$\Delta_{\mathrm{f}} H_{908 \mathrm{~K}} /\left(\mathrm{kJ} \cdot \mathrm{mol}^{-1}\right)$ & $\mathrm{Fe}_{2} \mathrm{P}$ & calorimetric measurement & -48.1 & 33 \\
\hline$\Delta_{\mathrm{f}} H_{1200 \mathrm{~K}} /\left(\mathrm{kJ} \cdot \mathrm{mol}^{-1}\right)$ & $\mathrm{Fe}_{2} \mathrm{P}$ & the second law analysis & -50.0 & 5 \\
\hline \multirow[t]{3}{*}{$\Delta_{\mathrm{f}} H_{298 \mathrm{~K}} /\left(\mathrm{kJ} \cdot \mathrm{mol}^{-1}\right)$} & $\mathrm{FeP}$ & the second law analysis & $-52.5 \pm 3.5$ & 5 \\
\hline & & the second law analysis & $-60.4 \pm 6.3$ & 35 \\
\hline & & first-principles calculations & -82.5 & 3 \\
\hline$\Delta_{\mathrm{f}} H_{900 \mathrm{~K}} /\left(\mathrm{kJ} \cdot \mathrm{mol}^{-1}\right)$ & $\mathrm{FeP}$ & Knudsen effusion & -59.9 & 34 \\
\hline$\Delta_{\mathrm{f}} H_{1200 \mathrm{~K}} /\left(\mathrm{kJ} \cdot \mathrm{mol}^{-1}\right)$ & $\mathrm{FeP}$ & the second law analysis & -55.1 & 5 \\
\hline \multirow[t]{2}{*}{$\Delta_{\mathrm{f}} \mathrm{H}_{298 \mathrm{~K}} /\left(\mathrm{kJ} \cdot \mathrm{mol}^{-1}\right)$} & $\mathrm{FeP}_{2}$ & the second law analysis & $-62.2 \pm 5.7$ & 35 \\
\hline & & first-principles calculations & -95 & 3 \\
\hline$\Delta_{\mathrm{f}} H_{900 \mathrm{~K}} /\left(\mathrm{kJ} \cdot \mathrm{mol}^{-1}\right)$ & $\mathrm{FeP}_{2}$ & Knudsen effusion & $-60.8 \pm 2.8$ & 34 \\
\hline$\Delta_{\mathrm{f}} H_{298 \mathrm{~K}} /\left(\mathrm{kJ} \cdot \mathrm{mol}^{-1}\right)$ & $\mathrm{FeP}_{4}$ & first-principles calculations & -87.1 & 3 \\
\hline
\end{tabular}

Table 3 Lattice stability parameters used in the present optimization

\begin{tabular}{|c|c|c|c|c|}
\hline Element & Phase & Lattice stability parameter & $T / \mathrm{K}$ & Reference \\
\hline \multirow[t]{8}{*}{$\mathrm{Fe}$} & \multirow[t]{2}{*}{$\mathrm{L}$} & ${ }^{0} G_{\mathrm{Fe}}^{\mathrm{L}}-{ }^{0} G_{\mathrm{Fe}}^{\alpha}=12040.17-6.55843 T-3.6751551 \times 10^{-21} T^{7}$ & $298.15-1811$ & 36 \\
\hline & & $=-10839.7+291.302 T-46 T \ln T$ & $1811-6000$ & 36 \\
\hline & \multirow[t]{3}{*}{$\alpha$} & ${ }^{0} G_{\mathrm{Fe}}^{\alpha}-{ }^{0} H_{\mathrm{Fe}}^{\alpha}=1225.7+124.134 T-23.5143 T \ln T-0.00439752 T^{2}-5.8927 \times 10^{-8} T^{3}+77359 T^{1}$ & $298.1-1811$ & 36 \\
\hline & & $=-25383.581+299.31255 T-46 T \ln T+2.29603 \times 10^{31} T^{9}$ & $1811-6000$ & 36 \\
\hline & & $T_{\mathrm{cre}}^{\alpha}=1043, \beta_{\mathrm{Fe}}^{\alpha}=2.22$ & $298.15-6000$ & 36 \\
\hline & \multirow[t]{3}{*}{$\gamma$} & ${ }^{0} G_{\mathrm{Fe}}^{\mathrm{y}}-{ }^{0} H_{\mathrm{Fe}}^{\prime}=-1462.4+8.282 T-1.15 T \ln T+6.4 \times 10^{-4} T^{2}$ & $298.15-1811$ & 36 \\
\hline & & $=-27098.266+300.25256 T-46 T \ln T+2.78854 \times 10^{31} T^{-9}$ & $1811-6000$ & 36 \\
\hline & & $T_{\mathrm{NPe}}^{\gamma}=67, \beta_{\mathrm{fe}}^{y}=0.7$ & $298.15-6000$ & 36 \\
\hline \multirow[t]{11}{*}{$\mathrm{P}$} & \multirow[t]{2}{*}{$\mathrm{L}$} & ${ }^{0} G_{\mathrm{P}}^{L}-{ }^{0} H_{\mathrm{P}}^{\text {white }}=-26316.111+434.943931 T-70.7440584 T \ln T-0.002898936 T^{2}+3.9049341 \times 10^{-5} T^{3}+1141.47 T^{-1}$ & $275-342.3$ & 36 \\
\hline & & $=-7232.449+133.304873 T-26.326 T \ln T$ & $342.3-6000$ & 36 \\
\hline & $\alpha$ & ${ }^{0} G_{\mathrm{P}}^{\alpha}-{ }^{0} H_{\mathrm{P}}^{\text {red }}=44769-13.26 T$ & $298.15-6000$ & 36 \\
\hline & $\gamma$ & ${ }^{0} G_{\mathrm{P}}^{p}-{ }^{0} H_{\mathrm{P}}^{\mathrm{red}}=37656-13.26 T$ & $298.15-6000$ & 36 \\
\hline & \multirow[t]{4}{*}{ red } & ${ }^{0} G_{\mathrm{P}}^{\text {Red }}-{ }^{0} G_{\mathrm{P}}^{\text {white }}=-25976.559+148.685002 T-25.55 T \ln T+0.0034121 T^{2}-2.418867 \times 10^{-6} \mathrm{~T}^{3}+160095 T^{-1}$ & $275-500$ & 36 \\
\hline & & $=-21723.721+77.684737 T-14.368 T \ln T-0.00957685 T^{2}+3.93917 \times 10^{-7} T^{3}-141375 T^{-1}$ & $500-852.35$ & 36 \\
\hline & & $=-119408.413+1026.04262 T-149.449556 T \ln T+0.067272364 T^{2}-6.651929 \times 10^{-6} T^{3}+1249543 T^{-1}$ & $852.35-1500$ & 36 \\
\hline & & $=-24524.119+153.852181 T-26.326 T \ln T$ & $1500-3000$ & 36 \\
\hline & \multirow[t]{3}{*}{ white } & ${ }^{0} G_{\mathrm{P}}^{\text {white }}-{ }^{0} H_{\mathrm{P}}^{\text {white }}=-43821.799+1026.70689 T-178.426 T \ln T+0.290708 T^{2}-1.04022667 \times 10^{-4} T^{3}+1632695 T^{-1}$ & $250-317.3$ & 36 \\
\hline & & $=-9587.448+152.354487 T-28.7335301 T \ln T+0.001715669 T^{2}-2.2829 \times 10^{-7} T^{3}+172966 T^{-1}$ & $317.3-900$ & 36 \\
\hline & & $=-8093.075+135.889831 T-26.326 T \ln T$ & $900-3000$ & 36 \\
\hline
\end{tabular}

$G$ and $H$ are in $\mathrm{J} \cdot \mathrm{mol}^{-1}, T_{\mathrm{c}}$ and $T_{\mathrm{N}}$ are Curie temperature and Neel temperature in $\mathrm{K}$, respectively, and $\beta$ is magnetic moment in $\mathrm{J} \cdot \mathrm{T}^{-1}$. 
Table 4 Optimized thermodynamic parameters of the Fe-P system

\begin{tabular}{|c|c|c|}
\hline Phase & Formula & Parameter \\
\hline liquid & $(\mathrm{Fe}, \mathrm{P})_{1}$ & ${ }^{0} L_{\mathrm{Fe}, \mathrm{P}}=-240000+45 T,{ }^{2} L_{\mathrm{Fe}, \mathrm{P}}^{\operatorname{liq}}=110000-59 T$ \\
\hline$\alpha-\mathrm{Fe}$ & $(\mathrm{Fe}, \mathrm{P})_{1}$ & ${ }^{0} L_{\mathrm{Fe}, \mathrm{P}}^{\alpha}=-172000+4.7 T$ \\
\hline$\gamma$-Fe & $(\mathrm{Fe}, \mathrm{P})_{1}$ & ${ }^{0} L_{\mathrm{Fe}, \mathrm{P}}^{\gamma}=-156000+6.0 T$ \\
\hline $\mathrm{Fe}_{3} \mathrm{P}$ & $(\mathrm{Fe})_{0.75}(\mathrm{P})_{0.25}$ & $\begin{aligned}{ }^{0} G_{\mathrm{Fe}: \mathrm{P}}^{\mathrm{Fe}}=- & -49167.25125+157.35 T-27.725 T \ln T- \\
& 0.0014625 T^{2}+134875 T^{1}\end{aligned}$ \\
\hline $\mathrm{Fe}_{2} \mathrm{P}$ & $(\mathrm{Fe})_{0.667}(\mathrm{P})_{0.333}$ & $\begin{aligned}{ }_{3}^{0} G_{\mathrm{Fe}: \mathrm{P}}^{\mathrm{Fe}}= & -59047.3333+121.523 T-22.2233 T \ln T- \\
& 0.0047833333 T^{2}\end{aligned}$ \\
\hline $\mathrm{FeP}$ & $(\mathrm{Fe})_{0.5}(\mathrm{P})_{0.5}$ & ${ }^{0} G_{\text {Fe: } \mathrm{P}}^{\text {Fep }}=-77409.25-21.125 T \ln T-0.005225 T^{2}+119.58 T$ \\
\hline $\mathrm{FeP}_{2}$ & $(\mathrm{Fe})_{0.333}(\mathrm{P})_{0.667}$ & ${ }_{7}^{0} G_{\mathrm{Fe}: \mathrm{P}}^{\mathrm{FeP}}-0.333 \times{ }^{0} G_{\mathrm{Fe}}^{\text {bce }}-0.667 \times{ }^{0} G_{\mathrm{P}}^{\text {white }}=-76666+16.33 T$ \\
\hline $\mathrm{FeP}_{4}$ & $(\mathrm{Fe})_{0.2}(\mathrm{P})_{0.8}$ & ${ }^{0} G_{\mathrm{Fe}: \mathrm{P}}^{\mathrm{FeP}}-0.2 \times{ }^{0} G_{\mathrm{Fe}}^{\mathrm{bce}}-0.8 \times{ }^{0} G_{\mathrm{P}}^{\text {white }}=-62000+14.6 T$ \\
\hline \multicolumn{3}{|c|}{$\begin{array}{l}\text { Reference states are } \alpha-\mathrm{Fe} \text { and red_P; Gibbs energies in } \mathrm{J} \cdot \mathrm{mol}^{-1} \text { and } \\
\text { temperatures in } \mathrm{K} \text {, and } L \text { is dimensionless parameter. }\end{array}$} \\
\hline
\end{tabular}

where $a_{i}, b_{i}$, and $c_{i}$ are model parameters to be optimized based on the experimental data in this study.

\section{Optimization procedure and results}

Based on the lattice stability parameters of $\mathrm{Fe}$ and $\mathrm{P}$ in Table 3 cited from references ${ }^{36}$ as well as the experimental phase diagram and thermodynamic property data summarized in Tables 1 and 2, all the values of the model parameters for the phases in this system were optimized by use of the PARROT module, which works by minimizing the square sum of the differences between the experimental data and calculated values, in the Thermo-Calc ${ }^{\circledR}$ software package developed by Sundman et al. ${ }^{8}$ In the optimization procedure, each selected experimental value has been given a weight according to the reliability and compatibility of the experimental data. The weight can be changed to achieve a satisfactory description of most of the experimental data. The optimized thermodynamic parameters for all condensed phases in the Fe-P system are summarized in

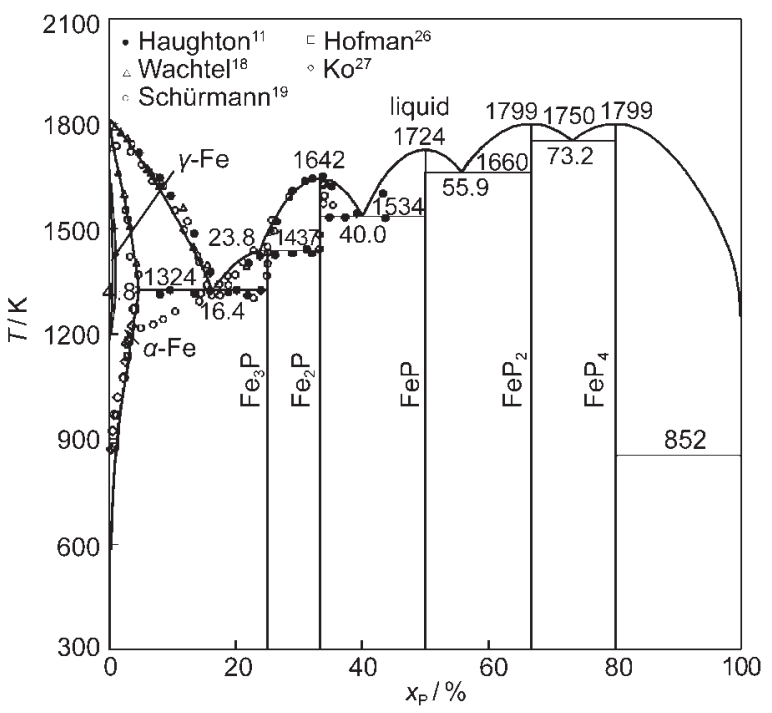

Fig.1 Fe-P phase diagram calculated by the present thermodynamic description with the experimental data
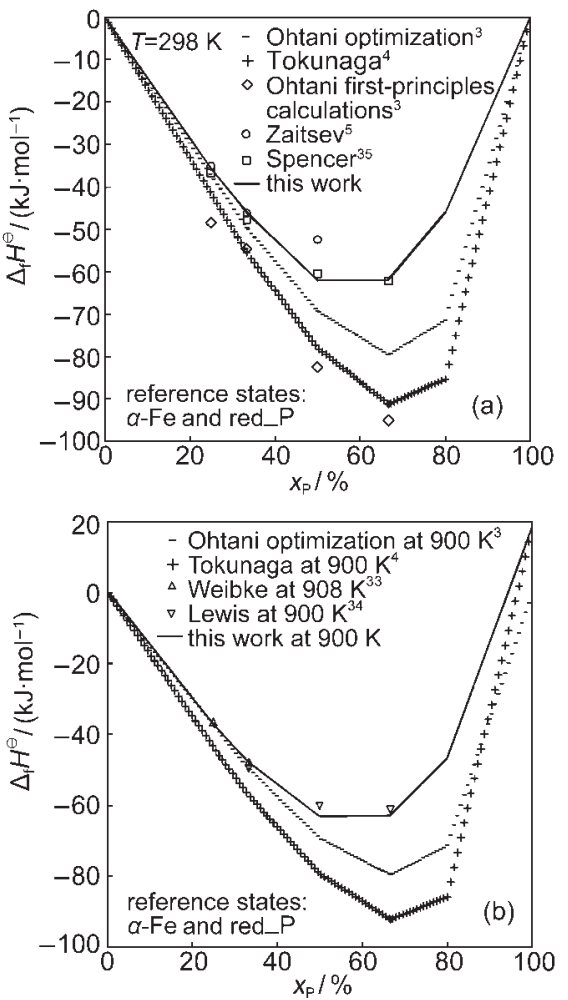

Fig.2 Calculated standard formation enthalpy at $298 \mathrm{~K}$ (a) and $900 \mathrm{~K}(\mathrm{~b})$ in the Fe-P system and comparison with the literature data

Table 4. The calculated temperatures and compositions of all invariant reactions in this system are compared with the experimental data in Table 1.

As shown in Fig.1 and Table 1, Schürmann's experimental result $^{19}$ of the reaction $\mathrm{L} \rightleftharpoons \alpha-\mathrm{Fe}+\mathrm{Fe}_{3} \mathrm{P}$ are lower than others'. Haughton $^{11}$ pointed that in the low-phosphorous alloys under-cooling of the eutectic was very marked, and this may account for the extraordinary shape given to the eutectic line by Schurmann. ${ }^{19}$ Therefore, the calculated liquidus and solidus as well as temperatures and compositions of all invariant reactions in the Fe-P $(0 \%-50 \% \mathrm{P})$ system agree well with the experimental data, especially reported in some references ${ }^{11,18,26,27}$

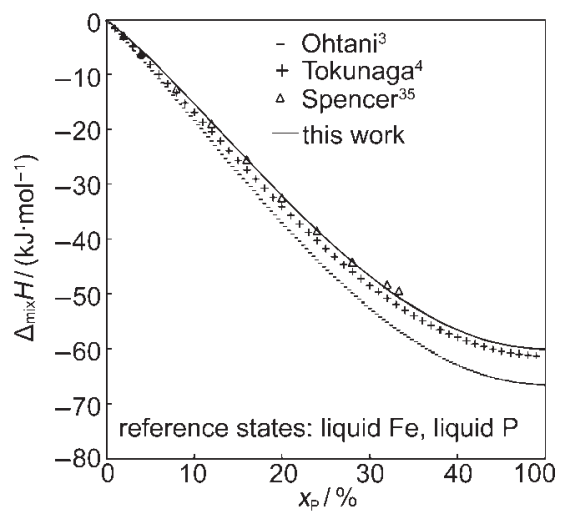

Fig.3 Calculated mixing enthalpy of liquid at $1809 \mathrm{~K}$ in the Fe-P system with the literature data 

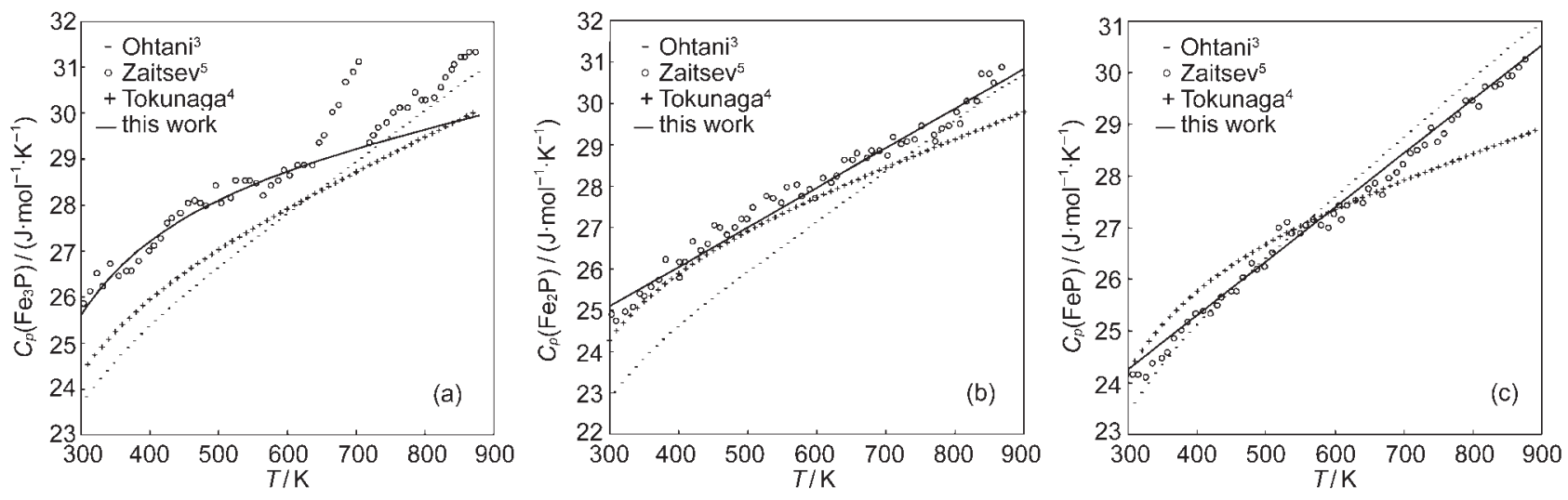

Fig.4 Calculated heat capacity of $\mathrm{Fe}_{3} \mathrm{P}(\mathrm{a}), \mathrm{Fe}_{2} \mathrm{P}(\mathrm{b})$, and $\mathrm{FeP}(\mathrm{c})$ with the literature data

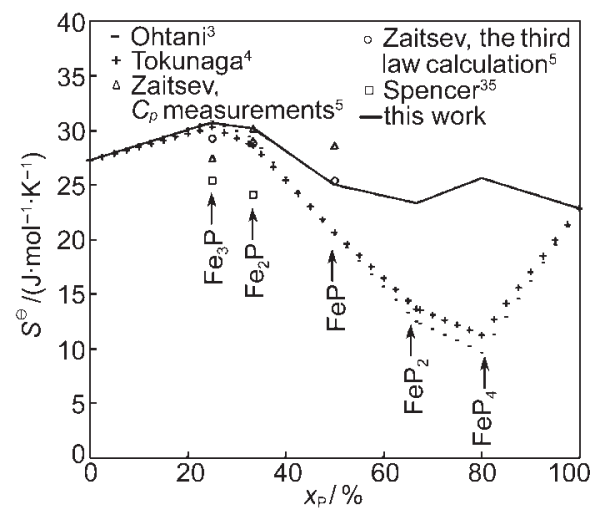

Fig.5 Calculated absolute entropy in the Fe-P system with the literature data

and the previous results assessed by Okamoto ${ }^{1}$ and Ohtani et $a l{ }^{3}$ As the part of $\mathrm{Fe}-\mathrm{P}(50 \%-100 \% \mathrm{P})$, there is no experimental information compared with calculated phase diagram. But, if compared the present calculated phase diagram with the previous assessed one ${ }^{3}$ the former is a little more reasonable than the latter.

Fig. 2 compares the calculated values of formation enthalpies of the Fe-P system at 298 and $900 \mathrm{~K}$ in this study with the literature data. Obviously, the present calculated values are in good agreement with measured ${ }^{5}$ and evaluated ${ }^{35}$ data at $298 \mathrm{~K}$ as well as with measured data at $900 \mathrm{~K}^{33,34}$ However, the values evaluated by Ohtani et al. ${ }^{3}$ and Tokunaga et al. ${ }^{4}$ and predicted using first-principles calculations ${ }^{3}$ are more negative than the experimental measured data. ${ }^{5}$

Fig. 3 presents the calculated $\Delta_{\text {mix }} H$ of liquid Fe-P system at $1809 \mathrm{~K}$ compared with the experimental data. ${ }^{3,435}$ It is clear that the present calculated values agree well with evaluated data by Spencer et al. ${ }^{35}$

It can be seen from Fig. 4 and Fig. 5 that agreement between present calculated heat capacities and absolute entropies of $\mathrm{Fe}_{3} \mathrm{P}, \mathrm{Fe}_{2} \mathrm{P}$, and $\mathrm{FeP}$ with measured data ${ }^{5}$ is better than the one between previous evaluated data ${ }^{3,4}$ with measured data.

\section{Conclusions}

Based on all available experimentally measured thermody- namic properties and phase diagram data, the Fe-P system, which is a significant binary one of the Fe-based and P-containing multicomponent alloys, was reoptimized by CALPHAD approach and Thermo-Calc ${ }^{\circledR}$ software package. The agreement between the optimized Fe-P $(0 \%-50 \% \mathrm{P})$ phase diagram and experimentally measured data is good enough. The calculated Fe-P $(50 \%-100 \% \mathrm{P})$ phase diagram is a little more reasonable than previously assessed one. The comparison of calculated formation entropies of the Fe-P system at 298 and $900 \mathrm{~K}$, calculated mixing entropies of the Fe-P system at $1809 \mathrm{~K}$ as well as calculated heat capacities of $\mathrm{Fe}_{3} \mathrm{P}, \mathrm{Fe}_{2} \mathrm{P}$, and $\mathrm{FeP}$ in this study with the measured data available from literature remains fairly good. An obtained thermodynamic description with self-consistency describing all the phases in the Fe-P system is better than that of the previous assessment.

\section{References}

(1) Okamoto, H. Bulletin of Alloy Phase Diagrams 1990, 11, 404.

(2) Kubaschewski, O. Iron-Binary Phase Diagrams; Springer-Verlag: Berlin, 1982; pp 84-86.

(3) Ohtani, H.; Hanaya, N.; Hasebe, M.; Teraoka, S.; Abe, M. CALPHAD 2006, 30, 147.

(4) Tokunaga, T.; Hanaya, N.; Ohtani, H.; Hasebe, M. ISIJ International 2009, 49, 947.

(5) Zaitsev, A. I.; Dobrokhotova, Z. V.; Litvina, A. D.; Mogutnov, B. M. J. Chem. Soc. Faraday Trans. 1995, 91, 703.

(6) Kaufman, L.; Bernstein, H. Computer Calculation of Phase Diagrams; Academic Press: New York, 1970.

(7) Saunders, N.; Modwnik, A. P. CALPHAD-a Comprehensive Guide; Pergamon, Lausanne: Switzerland, 1998.

(8) Sundman, B.; Jansson, B.; Anderson, J. O. CALPHAD 1985, 9 , 153.

(9) Saklatwalla, B. J. Iron Steel Inst. 1908, 77, 92.

(10) Konstantinow, N. Z. Anorg. Chem. 1910, 66, 209.

(11) Haughton, J. L. J. Iron Steel Inst. 1927, 115, 417.

(12) Vogel, R. Arch. Eisenhüttenwes. 1929-1930, 3, 369.

(13) Roquet, P.; Jegaden, G. Rev. Metall. 1951, 48, 712.

(14) Lorenz, K.; Frabritius, H. Arch. Eisenhüttenwes. 1962, 33, 269. 
(15) Fisher, W. A.; Lorenz, K.; Fabritius, H.; Hoffmann, A.; Kalwa, G. Arch. Eisenhüttenwes. 1966, 37, 79.

(16) Gercke, E. Metallurgie 1908, 5, 604.

(17) Hanemann, H.; Voss, H. Zentr. Hutten. Walzwerke 1927, 31, 245.

(18) Wachtel, E.; Urbain, G.; Ubelacker, E. Compt. Rend. 1963, 257, 2470 .

(19) Schürmann, E.; Kaiser, H. P.; Hensgen, U. Arch Eisenhüttenwes. 1981, 52, 51.

(20) Kaneko, H.; Nishizawa, T.; Tamaki, K.; Tanifuji, A. Nippon Kinzoku Gakkai-Shi 1965, 29, 166.

(21) Kreutzer, C. Z. Phys. 1928, 48, 556.

(22) Oberhoffer, P.; Kreutzer, C. Arch. Eisenhüttenwes. 1929, 2, 449.

(23) Yensen, T. D. Trans. Am. Inst. Elec. Eng. 1924, 43, 145.

(24) Svechnikov, V. N.; Pan, V. M. Phys. Met. Metallogr. 1958, 6, 80.

(25) Doan, A. S., Jr.; Goldstein, J. I. Metall. Trans. 1970, 1, 1759.

(26) Hofman, H. P.; Lohberg, K.; Reif, W. Arch. Eisenhüttenwes.
1970, 41, 975 .

(27) Ko, M.; Nishizawa, T. J. Jpn. Inst. Met. 1979, 43, 118.

(28) Franke, W.; Meisel, K.; Juza, R. Z. Anorg. Chem. 1934, 218, 346.

(29) Meisel, K. Z. Anorg. Chem. 1934, 218, 360.

(30) Heimbrecht, M.; Biltz, W. Z. Anorg. Chem. 1939, 242, 233.

(31) Holseth, H.; Kjekshus, A. Acta Chemica Scandinavica 1968, 22, 3273.

(32) Jeitschko, W.; Braun, D. J. Acta Crystallogr. B 1978, 34, 3196.

(33) Weibke, F.; Schrag, G. Elektrochemische Kinetik 1941, 47, 222.

(34) Lewis, G.; Myers, C. E. J. Phys. Chem. 1963, 67, 1289.

(35) Spencer, P.; Kubaschewski, O. A. Arch. Eisenhüttenwes. 1978, $49,225$.

(36) Dinsdale, A. T. CALPHAD 1991, 15, 317.

(37) Carsson, B.; Golin, M.; Rundqvist, S. J. Solid State Chem. 1973, 8,57 .

(38) Redlich, O.; Kister, A. T. Ind. Eng. Chem. 1948, 40, 345.

\section{中国化学会第 28 届学术年会通知}

中国化学会第28届学术年会将于 2012年4月 13-16日在四川省成都市举行。本届年会 由中国化学会主办, 四川大学承办, 会期 4 天, 4 月 12 日报到。2012 年正值中国化学会成立八 十周年, 届时将举办相关庆祝活动。

本届年会设立学术分会 19 个、专题论坛 4 个。学术交流形式包括大会特邀报告(PL)、分会 邀请报告 $(\mathrm{I})$ 、口头报告 $(\mathrm{O})$ 和墙报 $(\mathrm{P})$ 。年会面向全国广大化学工作者征集学术论文(摘要), 并 印制论文摘要集, 欢迎踊跃投稿, 积极参会。

年会期间将举办新技术、新产品与新仪器成果展览以及人才交流活动, 欢迎相关企业、高 校、科研院所积极参与。

会议详细内容请见会议网站: http://www.ccs.ac.cn/confab/huiyi.html 